\title{
Four Types of Streptococcus mutans Based on Their Genetic, Antigenic and Biochemical Characteristics
}

\author{
By A. L. COYKENDALL \\ Veterans Administration Hospital, Newington, Connecticut 06I I I, U.S.A. \\ (Received ro January I974; revised I I March I974)
}

\begin{abstract}
SUMMAR Y
Eighteen cariogenic streptococcal strains identified as members of Streptococcus mutans (Clarke, 1924) were compared on the basis of biochemical tests, mannitolI-phosphate dehydrogenases, DNA base compositions and DNA base sequence homologies. Some slight biochemical differences were found which correlated with the large differences in DNA base composition and sequence heterology which exist among these strains. All strains could be assigned to one of four groups based on these biochemical and genetic differences. Furthermore, these four groups correlated with four serological groups described by Bratthall (1970). It is proposed to divide $S$. mutans into four subspecies: $S$. mutans subsp. mutans, the type subspecies, has a guanine-cytosine $(\mathrm{G}-\mathrm{C})$ of 36 to $38 \mathrm{~mol} \%$ and belongs to Bratthall serological group $c ; S$. mutans subsp. rattus subsp. nov. has $4 \mathrm{I}$ to $43 \mathrm{~mol} \%$ G-C, belongs to Bratthall group $b$, and can be distinguished from the other subspecies by its production of ammonia from arginine; $S$. mutans subsp. cricetus subsp. nov. has 42 to $44 \mathrm{~mol} \% \mathrm{G}-\mathrm{C}$, belongs to Bratthall group $a$, and can be distinguished by its lack of growth in air; $S$. mutans subsp. sobrinus subsp. nov. has 44 to $46 \mathrm{~mol} \% \mathrm{G}-\mathrm{C}$, belongs to Bratthall group $d$, and can be distinguished by its failure to ferment raffinose.
\end{abstract}

\section{INTRODUCTION}

Streptococcus mutans was originally described by Clarke (1924), who believed that it caused dental caries. It was the subject of a few later reports (Maclean, 1927; Abercrombie \& Scott, 1928; Appleton, 1933), but interest in the species dwindled. Then, in the past decade, several unspeciated 'viridans' streptococci were shown to cause dental caries in gnotobiotic rats (Fitzgerald, Jordan \& Stanley, 1960; Gibbons, Berman, Knoettner \& Kapsimalis, 1966) and conventional hamsters (Fitzgerald \& Keyes, I960; Krasse, 1966; Zinner, Jablon, Aran \& Saslaw, I 965). Carlsson ( I967) noted the similarity between Clarke's description of $S$. mutans and certain of these cariogenic 'viridans' strains (Krasse, I966). Subsequently, Guggenheim (I968) and Edwardsson (I968) showed that most of the cariogenic streptococci conformed to the description of $S$. mutans. Since several of these cariogenic strains were of human origin (Zinner et al. I965; Gibbons et al. 1966; Krasse, I 966; Edwardsson, I968; Guggenheim, I968), and the presence of $S$. mutans on human teeth can be correlated with tooth decay (Krasse, Jordan, Svensson \& Trell, I968; de Stoppelaar, Van Houte \& Backer Dirks, 1969; Englander \& Jordan, 1972; Hoerman, Keene, Shklair \& Burmeister, 1972; Shklair, Keene \& Simonson, 1972), Clarke's species is now considered a major etiologic factor in human caries.

The fermentation of several sugars, including mannitol and sorbitol, plus production of glucans from sucrose, distinguish $S$. mutans from other streptococci (Carlsson, I967; Guggenheim, 1968). Several traits appear to enhance the bacterium's odontolytic potential. The glucans (Guggenheim \& Schroeder, 1967; Wood, 1967) may function as adhesives 
binding the streptococci to tooth surfaces (Gibbons \& Banghart, 1967) and promote formation of aggregates (Gibbons \& Fitzgerald, 1968). They store an intracellular iodophilic polysaccharide (Van Houte, de Moor \& Jansen, 1970; de Stoppelaar, I 97I) which probably can be catabolized in the absence of exogenous carbon sources (Gibbons, 1964; M. L. Freedman \& A. L. Coykendall, unpublished). Finally, the organism can produce a $\mathrm{pH}$ of 4.0 in sucrose medium (Edwardsson, I963).

Strains of $S$. mutans are phenotypically quite homogeneous, as demonstrated by numerical taxonomy (Carlsson, 1968; Drucker \& Melville, 1971).

Despite the phenotypic homogeneity of the species, recent investigations have revealed a remarkable degree of genetic and antigenic heterogeneity. Wide variations have been found in DNA base contents among $S$ mutans strains (Coykendall, I970; Dunny, Hausner \& Clewell, 1972), and DNA-DNA reassociation experiments have demonstrated four distinct genetic groups within the species (Coykendall, I97I ; Coykendall, Daily, Kramer \& Beath, $197 \mathrm{I}$ ). Intergroup reassociations were low, never greater than $55 \%$, and intergroup hybrids were thermolabile (Coykendall, 1971). Bratthall (1970) has described five serological groups within $S$. mutans: Bratthall $a, b, c, d$ and Lancefield E. Strains which react with Lancefield E antiserum cross-react with S. mutans group $c$ antiserum (Bratthall, 1972). The genetic groups correlate with the serological groups. Recently, enzymatic differences have been found among $S$. mutans strains which correlate with the antigenic and genetic groups (Brown \& Patterson, 1972; Brown \& Wittenberger, 1972). Differences have also been reported in the glucans produced by strains of different genetic groups (Newbrun, 1972). Some morphological differences have also been noted (Coykendall et al. 1971).

This communication reports the genetic position of several additional strains including four which react with Lancefield group E antiserum [Bratthall's (1970) fifth serological group], presents physiological patterns of the four groups which help to delineate them, and proposes that $S$. mutans be divided into four subspecies based on genetic and antigenic characters.

\section{METHODS}

Bacteria. The strains used in this study are listed in Table $\mathrm{I}$ with their antigenic and genetic group designations as determined in this or previous work. All were confirmed to be members of Streptococcus mutans, on the basis of phenotypic characters (Edwardsson, 1968; Guggenheim, 1968). Stock cultures were maintained in Todd-Hewitt broth (BBL) with calcium carbonate and $\mathrm{I} \%$ additional glucose. Cultures were periodically examined for typical growth on Mitis-salivarius agar (Difco) and for purity by streaking on blood agar or Trypticase Soy agar (BBL) and by examination of Gram-stained smears. Usually, cultures were grown anaerobically.

Biochemical tests. Sugar fermentations were tested in Cystine Trypticase agar (CTA; BBL) with I \% carbohydrate. The medium was autoclaved at I I $8{ }^{\circ} \mathrm{C}$. In some tests filtersterilized sugars were added after the medium was autoclaved; the results did not differ from those using autoclaved sugars. Inulin was dissolved in hot water and filter-sterilized. The production of ammonia from L-arginine- $\mathrm{HCl}$ was determined by the method of Niven, Smiley \& Sherman (1942). The inoculum was one drop of an I $8 \mathrm{~h}$ culture grown anaerobically in Todd-Hewitt broth and the CTA was stabbed several times with a sterile loop. A tube of CTA with no sugar was also inoculated.

The effect of various atmospheres on growth was tested by streaking a loop of culture on to each of three Trypticase Soy agar plates and incubating one each in air, a candle jar, and an anaerobic jar $\left(90 \% \mathrm{H}_{2}, 10 \% \mathrm{CO}_{2}\right.$; GasPak, BBL). 
Table I. Strains of S. mutans used in this study

\begin{tabular}{|c|c|c|c|c|c|c|}
\hline \multirow[b]{2}{*}{ Strain } & \multirow[b]{2}{*}{$\begin{array}{l}\text { Genetic } \\
\text { Group* }\end{array}$} & \multirow[b]{2}{*}{$\begin{array}{c}\text { Antigenic } \\
\text { Group } \dagger\end{array}$} & \multicolumn{2}{|c|}{$\begin{array}{l}\text { Guanine plus } \\
\text { cytosine (mol \%) }\end{array}$} & \multirow[b]{2}{*}{ Source } & \multirow[b]{2}{*}{ Remarks } \\
\hline & & & $\begin{array}{l}\text { From } \\
\text { Tm } \ddagger\end{array}$ & $\begin{array}{l}\text { From } \\
\mathrm{CsCl} \S\end{array}$ & & \\
\hline NCTCIO449 & I & $c$ & $37 \cdot 9$ & $37 \cdot I$ & $\begin{array}{l}\text { Human carious } \\
\text { lesion }\end{array}$ & $\begin{array}{l}\text { Cariogenic for hamsters, Ed- } \\
\text { wardsson (I968). Derived from } \\
\text { NCTCIO449 }\end{array}$ \\
\hline GS5 & I & $c$ & $37 \cdot 7$ & $36 \cdot 9$ & $\begin{array}{l}\text { Human carious } \\
\text { lesion }\end{array}$ & $\begin{array}{l}\text { Cariogenic for gnotobiotic rats, } \\
\text { Gibbons et al. (1966) }\end{array}$ \\
\hline Ingbritt & I & $c$ & $37 \cdot \mathrm{I}$ & $37 \cdot 5$ & $\begin{array}{l}\text { Human buccal } \\
\text { plaque }\end{array}$ & $\begin{array}{l}\text { Cariogenic for hamsters, Krasse } \\
\text { (I966) }\end{array}$ \\
\hline FAI & II & $b$ & $42 \cdot 2$ & $4 I \cdot 3$ & Rat mouth & $\begin{array}{l}\text { Cariogenic for gnotobiotic rats, } \\
\text { Fitzgerald et al. (1960). Believed } \\
\text { identical to ATCC } 9645\end{array}$ \\
\hline BHT & II & $b$ & $43 \cdot 4$ & $4 \mathrm{r} \cdot 7$ & $\begin{array}{l}\text { Human carious } \\
\text { lesion }\end{array}$ & $\begin{array}{l}\text { Cariogenic for hamsters, Zinner } \\
\text { \& Jablon (1968) }\end{array}$ \\
\hline SLI & III & $d$ & $45 \cdot I$ & $44 \cdot 9$ & Human plaque & McCabe, Keyes \& Howell (1967) \\
\hline KIR & III & $d$ & $45 \cdot 2$ & $45 \cdot 3$ & Human plaque & $\begin{array}{l}\text { Cariogenic for gerbils, Fitzgerald } \\
\text { \& Fitzgerald (1965) }\end{array}$ \\
\hline OMzi76 & III! & $d$ & N.D. & $44 \cdot 7$ & $\begin{array}{l}\text { Human smooth- } \\
\text { surface plaque }\end{array}$ & $\begin{array}{l}\text { Cariogenic for rats, Guggenheim } \\
\text { (1968) }\end{array}$ \\
\hline $\mathrm{B} 13$ & III & $d$ & N.D. & N.D. & Human plaque & $\begin{array}{l}\text { Edwardsson (1968) (see also } \\
\text { Bratthall, I970) }\end{array}$ \\
\hline HS6 & IV! & N.D. & $42 \cdot 7 !$ & N.D. & $\begin{array}{l}\text { Plaque from } \\
\text { hamster } \\
\text { carious lesion }\end{array}$ & $\begin{array}{l}\text { Cariogenic for hamsters, Fitz- } \\
\text { gerald \& Keyes (1960). Believed } \\
\text { identical to ATCC1 } 9642\end{array}$ \\
\hline E49 & IV & $a$ & $43 \cdot 7$ & $4 I \cdot 8$ & & Streptomycin resistant HS6 \\
\hline AHT & IV & $a$ & $43 \cdot 7$ & $4 I \cdot 3$ & $\begin{array}{l}\text { Human carious } \\
\text { lesion }\end{array}$ & $\begin{array}{l}\text { Cariogenic for hamsters, Zinner } \\
\text { et al. (1965) }\end{array}$ \\
\hline oMz6r & IV & $a$ & $42 \cdot 7 \|$ & N.D. & Rat tooth & $\begin{array}{l}\text { Cariogenic for rats, Guggenheim, } \\
\text { König \& Mühlemann (I965) }\end{array}$ \\
\hline $\begin{array}{l}\text { LM7 } \\
\text { B2 } \\
\text { P4 } \\
\text { At IO }\end{array}$ & $\begin{array}{l}\mathbf{I} \\
\mathbf{I} i \\
\mathbf{I} \\
\mathbf{I}\end{array}$ & $\begin{array}{l}E \\
E \\
E \\
E\end{array}$ & $\begin{array}{l}\text { N.D. } \\
\text { N.D. } \\
\text { N.D. } \\
\text { N.D. }\end{array}$ & $\begin{array}{l}36 \cdot 6 \\
36 \cdot 9 \\
\text { N.D. } \\
\text { N.D. }\end{array}$ & Human plaque & $\begin{array}{l}\text { Among strains studied by Ed- } \\
\text { wardsson (1968). See Bratthal } \\
\text { (1970) }\end{array}$ \\
\hline SDI & $\begin{aligned} & I \\
& * \text { From } \\
&+ \text { From } \\
& \text { t From } \\
& \$ \text { From } \\
& \text { I Denot } \\
& \text { N.D., No }\end{aligned}$ & $\begin{array}{l}\text { this work } \\
\text { Bratthall ( } \\
\text { thermal de } \\
\text { CsCl dens } \\
\text { tes results } \\
\text { t done. }\end{array}$ & $37 \cdot 6$ & $\begin{array}{l}\text { results } \\
\text { Coyke } \\
t \text { al. I } \\
t \text { work }\end{array}$ & $\begin{array}{l}\text { Rat mouth } \\
\text { (Coykendall, 197I) } \\
\text { ndall, I970; and th } \\
72 \text {, and personal c }\end{array}$ & $\begin{array}{l}\text { Isolated by H. V. Jordan (per- } \\
\text { sonal communication) } \\
\text { is work). } \\
\text { ommunication). }\end{array}$ \\
\hline
\end{tabular}

Rate of glycolysis. The rate of change in $\mathrm{pH}$ of a weak buffer-washed bacterial suspension after the addition of a fermentable carbohydrate was used as a measure of the rate of glycolysis of that substrate. The experiments were designed to compare the rate of glycolysis of glucose with those of fructose and sucrose by strains of $S$. mutans.

Bacteria were grown to early stationary phase (determined turbidimetrically) in ToddHewitt broth $(0.2 \%$ glucose $)$, harvested, washed with $50 \mathrm{~mm}-\mathrm{KCl}+\mathrm{I} \mathrm{mm}$-phosphate buffer (pH 6.9), stored at $4{ }^{\circ} \mathrm{C}$ overnight, suspended in fresh buffer, and a $\mathrm{pH}$ electrode was immersed in the suspension while it was stirred at $37^{\circ} \mathrm{C}$. After temperature equilibration the 
suspension was brought to I mm-glucose, -fructose, or -sucrose; volumes were adjusted finally to $25 \mathrm{ml}$ with an absorbance of about 0.30 at $600 \mathrm{~nm}$ in a Bausch \& Lomb Spectronic 20 spectrophotometer. After addition of the sugar, the $\mathrm{pH}$ was recorded until it stabilized. The $\mathrm{pH}$ did not decrease in the absence of sugar.

Mannitol-I-phosphate dehydrogenase patterns. Brown \& Patterson (1972) have shown that the electrophoretic pattern of mannitol-I-phosphate dehydrogenase is specific for each genetic group of $S$. mutans. The patterns for the serological group E strains and strain SDI were determined using the methods described by Brown \& Patterson (1972). Strains NCTCI0449 and Ingbritt were assayed simultaneously for comparison.

Deoxyribonucleic acid. Deoxyribonucleic acids were extracted as previously described (Coykendall, 1970). Radioactive DNA from strain GS5 was obtained from D. B. Clewell. Base contents, as mol \% guanine plus cytosine, were determined by $\mathrm{CsCl}$ density (Schildkraut, Marmur \& Doty, 1962) or by thermal denaturation (Marmur \& Doty, 1962). Base-sequence homologies between strains were assessed by DNA-DNA reassociation on membrane filters (Denhardt, I 966) as detailed previously (Coykendall, 197I), except that thymidine-methyl[ $\left[{ }^{3} \mathrm{H}\right]$ was used instead of $\left[{ }^{14} \mathrm{C}\right]$ thymidine for labelling DNA and labelled GS5 DNA was sheared by sonication for $12 \mathrm{~s}$ at low power (Sonicator Model WI85, Heat Systems-Ultrasonics, Inc.). All reassociations were carried out at $67^{\circ} \mathrm{C}$ in $3 \times \mathrm{SSC}$ $(0.45 \mathrm{M}-\mathrm{NaCl}+0.045 \mathrm{M}$-sodium citrate).

Serology. To confirm the presence of serological group E antigens, HCl extracts (Lancefield, 1933) were prepared from cultures of alleged serological group E strains and several control strains grown overnight in Todd-Hewitt broth. The extracts were tested against commercial Lancefield group E antisera (Difco Laboratories, and Wellcome Reagents Ltd) in capillary tubes. A precipitate at the interface of antigen and antiserum was considered a positive reaction.

\section{RESULTS}

All strains fermented mannitol and inulin, and all but BI3 fermented sorbitol. Strains which reacted with Bratthall group $d$ antiserum (SLI, KIR, OMZI 76 and BI 3 ) did not ferment raffinose or melibiose. The Lancefield group E strains (LM7, B2, P4, At I0) and Streptococcus mutans strain SDI fermented raffinose very slowly. A positive colour change (to yellow) was observed only after 3 to 2 days. Slow growth with acid production could be observed along the agar stab and was a consistent observation. Melibiose was not fermented by these five strains. Strains FAI and BHT, which are very closely related to each other (Coykendall,197I) and comprise Bratthall's (1970) group $b$, were the only strains which produced ammonia from arginine. All strains grew best in the presence of $\mathrm{CO}_{2}$. Growth, judged by colony size, was as good in a candle jar as in the strictly anaerobic $\left(\mathrm{H}_{2}+\mathrm{CO}_{2}\right)$ atmosphere. In air, growth was slower, and strains Hs6, E49 and omz6r did not grow at all. Strain AHT grew feebly, producing very small colonies. Thus, genetic group IV strains appear to have a requirement for $\mathrm{CO}_{2}$ or an intolerance of oxygen.

Mannitol-I-phosphate dehydrogenase. The electrophoretic patterns of mannitol-I-phosphate dehydrogenases are shown in Fig. I. The pattern from strain SDI was identical to that of B2 and is not shown. Similarly, P4 and At Io patterns, which were identical to that of LM7, are not shown. There are two bands common to all strains. The Lancefield group E strains show some isozyme bands of lower mobility. Overall, the group E patterns resemble the patterns of genetic group I strains (NCTCIO449 and Ingbritt) when contrasted to the markedly different patterns produced by strains of other genetic groups (Brown \& Patterson, 1972). 


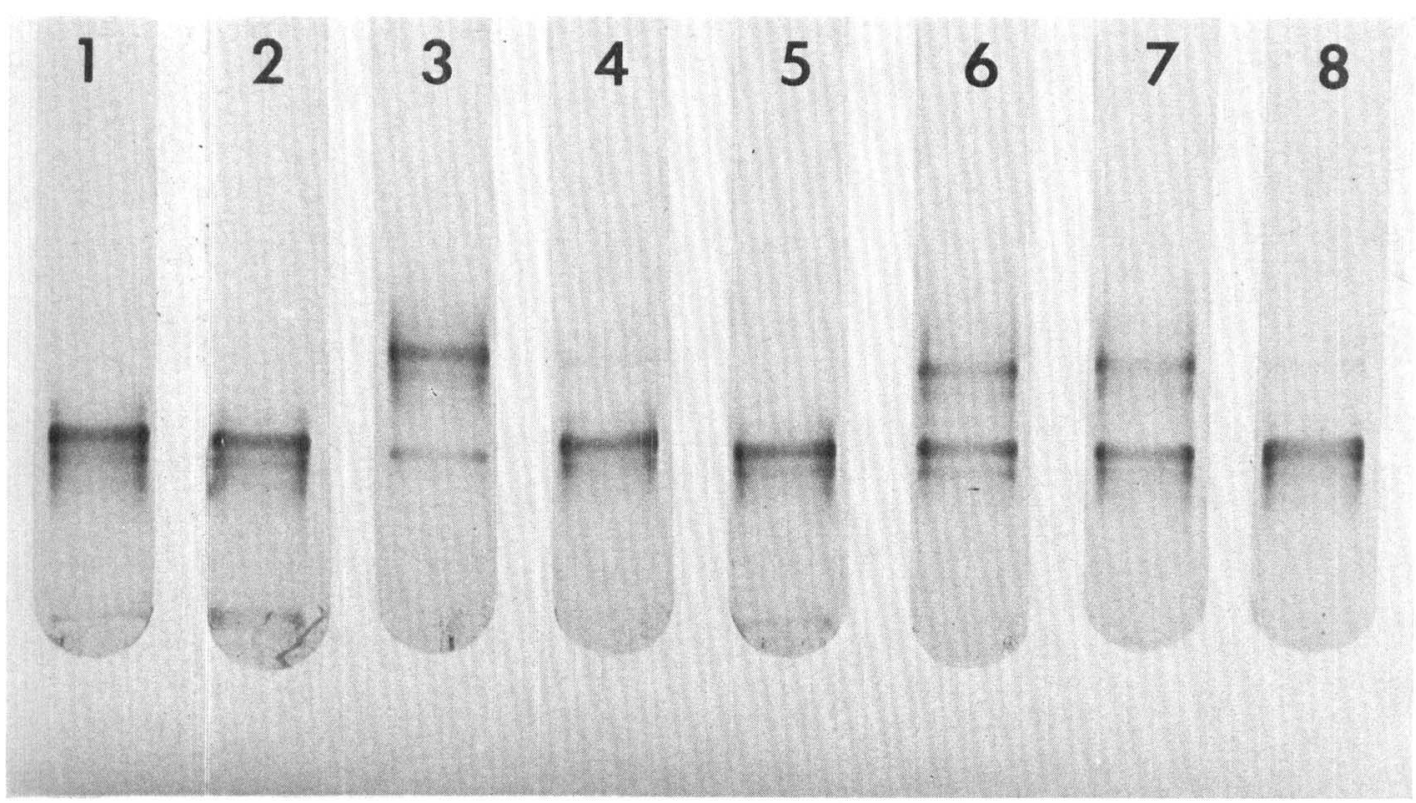

Fig. I. Electrophoretic patterns of mannitol-I-phosphate dehydrogenases from extracts of Streptococcus mutans strains. Extracts were applied to $7.5 \%$ polyacrylamide gels, pH 9.3 . (1) NCTC10449; (2) strain Ingbritt; (3) strain LM7; (4) strain B2; (5) mixture of extracts from NCTC 10449 and Ingbritt; (6) mixture of extracts from LM7 and B2; (7) mixture of extracts from NCTCIO449 and LM7; (8) mixture of extracts from NCTCIO449 and B2.

Rates of glycolysis. Washed, resting, glucose-grown bacteria metabolized glucose at a rate faster than sucrose, an observation reported previously by Tanzer, Brown \& Meyers (1972). However, the rate of glycolysis of fructose relative to the other sugars varied with the genetic group. In three genetic groups, the rate of fructose metabolism paralleled that of glucose (FAI and BHT, group II; HS6, E49, OMZ6I and AHT, group IV; SLI and BI3, group III: Bratthall serological groups $b, a$ and $d$, respectively). In the other strains tested, the rate of fructose metabolism paralleled the rate of sucrose metabolism (Ingbritt, GS5, NCTC10449, group I; SDI, LM7, B2: Bratthall serological group $c$ and Lancefield group E, respectively) (Fig. 2). If strains were grown in sucrose rather than glucose, all three sugars were metabolized at the same rate except in the case of GS5. Growth in sucrose did not induce rapid sucrose fermentation in this strain.

DNA base content and hybridization. The base contents of strains not previously reported are incorporated in Table I. Strains HS6, OMZ6I and AHT have DNA base contents close to that of strain E49; this was expected because of their serological similarity (Bratthall, I970). Radioactive omz6r DNA reassociated extensively with DNA of the other three strains (Table 2). Strain B 13 DNA reassociated only $43 \%$ with omz6I DNA which, on the basis of previous experiments (Coykendall, I97I), was about the value expected for DNA reassociation between genetic group III and group IV strains.

In a separate experiment, strain OMZI76 DNA was $81.5 \%$ homologous with strains KIR and SLI (group III, Bratthall serological group $d$ ).

The base contents of the serological group $\mathrm{E}$ strains and $S$. mutans strain SD I were similar to those of genetic group I (Bratthall serological group $c$ ) (Table I). Labelled LM7 DNA hybridized extensively with DNA from these five strains and also with DNA from NCTCI0449 (Table 3). In a reciprocal experiment, labelled GS5 DNA reassociated extensively with DNA 


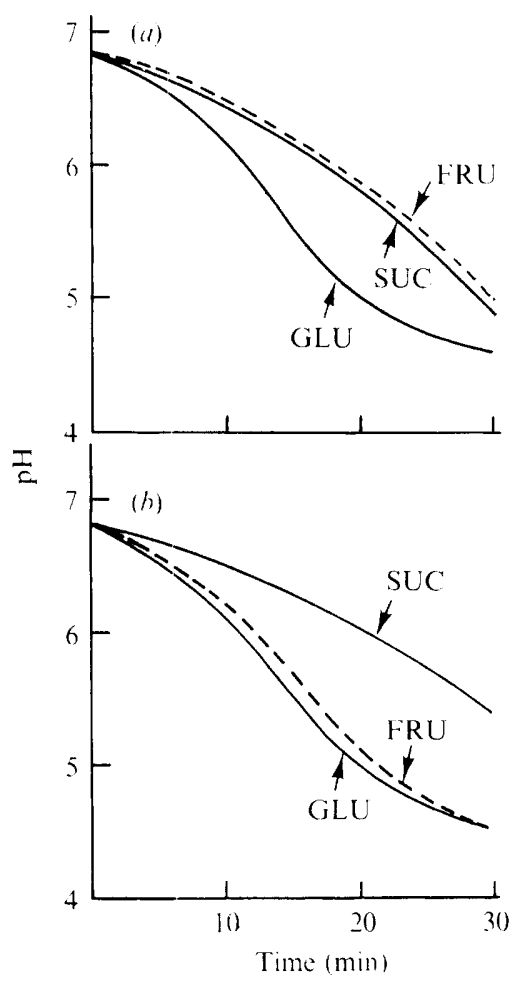

Fig. 2. Decrease of $\mathrm{pH}$ in washed, resting, glucose-grown bacterial suspensions in $50 \mathrm{~mm}-\mathrm{KCl}-\mathrm{I} \mathrm{mm}-$ phosphate buffer ( $\mathrm{pH} \mathrm{6.9)}$ after addition of carbohydrate to I mM. The pattern shown by $S$. mutans NCTCIO449 $(a)$ is typical of all strains in genetic group I. The pattern shown by $S$. mutans strain HS6 (b) is typical of strains in genetic groups II to IV. GLU, Glucose; FRU, fructose; SUC, sucrose.

Table 2. Extent of reassociation of DNA of genetic group IV strains with radioactive omz6r $D N A$ at $67^{\circ} \mathrm{C}$ in $3 \times S S C$

Radioactive omz6I DNA bound

Immobilized
DNA strands

OMz6I
AHT
HS6
E49
BI3 3
Escherichia coli

$\begin{array}{cc}\begin{array}{c}\% \text { of total } \\ {\left[{ }^{3} \mathrm{H}\right] \mathrm{DNA} \text { available }}\end{array} & \begin{array}{c}\% \text { relative } \\ \text { to omz6 I }\end{array} \\ 5 \mathrm{I} \cdot 6 & \mathrm{I00} \\ 5 \mathrm{I} \cdot 4 & 99.4 \\ 50 \cdot 3 & 97.2 \\ 50 \cdot 8 & 98 \cdot 3 \\ 23.5 & 45.5 \\ \text { I.5 } & 2.9\end{array}$

from serological group E strains and, as expected, with DNA from NCTC10449. These experiments indicate that the Lancefield serological group E strains and SDI are genetically indistinguishable from genetic group I strains.

Serology. Extracts from the strains reported by Bratthall (1970) to react with Lancefield group E antiserum gave a positive precipitin test with both Difco and Wellcome anti-E sera. Strain SDI, which is biochemically similar to serological group E strains, was not positive for the E antigen nor were the controls (NCTCr0449, HS6, SLI). 
Table 3. Reassociation between DNA from Lancefield group E and genetic group $I$ S. mutans strains at $67^{\circ} \mathrm{C}$ in $3 \times S S C$

\begin{tabular}{|c|c|c|c|c|}
\hline \multirow[b]{2}{*}{$\begin{array}{l}\text { Immobilized } \\
\text { DNA strands }\end{array}$} & \multicolumn{2}{|c|}{ Radioactive LM7 DNA bound } & \multicolumn{2}{|c|}{ Radioactive GS5 DNA bound } \\
\hline & $\begin{array}{c}\% \text { of total }\left[{ }^{3} \mathrm{H}\right] \text { DNA } \\
\text { available }\end{array}$ & $\begin{array}{l}\% \text { relative } \\
\text { to } \mathrm{LM} 7-\mathrm{LM} 7\end{array}$ & $\begin{array}{c}\% \text { of total }\left[{ }^{3} \mathrm{H}\right] \mathrm{DNA} \\
\text { available }\end{array}$ & $\begin{array}{l}\% \text { relative } \\
\text { to GS5-GS5 }\end{array}$ \\
\hline LM7 7 & $42 \cdot 6$ & $100 \cdot 0$ & $40 \cdot 6$ & $76 \cdot 0$ \\
\hline $\mathrm{B} 2$ & $37 \cdot I$ & $87 \cdot 2$ & $51 \cdot 0$ & $94 \cdot 9$ \\
\hline P4 & $38 \cdot 0$ & $89 \cdot 3$ & $53 \cdot 8$ & $100 \cdot 2$ \\
\hline At 10 & $38 \cdot 6$ & $90 \cdot 6$ & $5 I \cdot 6$ & $96 \cdot 1$ \\
\hline SDI & $40 \cdot 8$ & $95 \cdot 9$ & $67 \cdot 0$ & 123.0 \\
\hline 10449 & $36 \cdot 7$ & $86 \cdot 2$ & $53 \cdot 5$ & $99 \cdot 7$ \\
\hline GS5 & Not done & - & $53 \cdot 7$ & $100 \cdot 0$ \\
\hline Escherichia coli & $\mathrm{I} \cdot \mathrm{I}$ & $2 \cdot 6$ & $2 \cdot 6$ & $4 \cdot 9$ \\
\hline
\end{tabular}

\section{DISCUSSION}

The results presented here support previous evidence that Streptococcus mutans strains can be assigned to one of four genetic groups and that these groups correlate with four of Bratthall's five serologic groups.

Members of the fifth serologic group react with Lancefield group E antiserum. Although biochemically different from other serological group E streptococci [S. infrequens (Deibel, Yao, Jacobs \& Niven, 1964; de Moor \& Thal, 1968) and S. uberis (Cullen, 1967)], these Streptococcus mutans strains of serological group E resemble $S$. uberis strains of serological group $\mathrm{E}$ in their inability to evoke group $\mathrm{E}$ antiserum when injected into rabbits (Bratthall, 1970; Cullen, 1967). They resemble $S$. mutans genetic group I strains in their slow glycolysis of fructose and in some mannitol-I-phosphate dehydrogenase isozymes. Genetically, the serological group E strains are so closely related to the genetic group I strains as to be indistinguishable by the DNA reassociation techniques used here. Furthermore, these strains cross-react with antiserum to genetic group I strains (Bratthall serological group $c$ ) (Bratthall, 1972), and Hardie \& Bowden (1971) have shown that serological group E and genetic group I strains have the same carbohydrates in their cell walls. It is reasonable to consider the serological group E strains as variants of genetic group I. It is interesting to note that strain SDI, which resembles the serological group E strains, did not react with commercial group E antisera.

Differences in biochemical properties among $S$. mutans strains such as reaction to raffinose and arginine have been observed by others (Edwardsson, 1968; Guggenheim, 1968). However, these differences are seen to correlate with the genetic groups. Thus the members of genetic group III (Bratthall serological group $d$ ) can be identified by their failure to ferment raffinose and those of group II can be identified by the production of ammonia from arginine. Strains of genetic groups I (Bratthall serological group c) and IV (Bratthall serological group $a$ ) are biochemically very similar but can be separated by the reluctance of genetic group IV strains to grow in air.

The difference in the rate of metabolism of fructose relative to glucose and sucrose in genetic group I strains compared with all other strains does not constitute a rapid means of identification and is more of academic interest. The dissimilation of sucrose in $S$. mutans is complex (Tanzer, 1972). It is known that sucrose is metabolized more rapidly if cells are grown in sucrose (Tanzer, Brown \& Meyers, 1972). Thus the fate of sucrose is determined, at least in part, by an inducible system, probably invertase (Gibbons, 1972; Tanzer, Brown \& 
McInerney, I973). The experiments with fructose reported here demonstrate that in genetic group I strains, rapid fructose metabolism is, like the metabolism of sucrose, not constitutive (as it is in other strains) but is induced by growth in sucrose. The failure of sucrose-grown GS5 to ferment sucrose rapidly may be due to the low level of invertase observed when this strain is grown on sucrose (Kuramitsu, 1973). Other $S$. mutans strains have increased levels of invertase after growth in sucrose (Tanzer, Brown \& McInerney, 1973).

Organisms phenotypically homogeneous but genetically heterogeneous present a taxonomic dilemma. If genetic relatedness completely determined taxonomy Escherichia coli would be considered a member of the genus Shigella (Brenner, Fanning, Miklos \& Steigerwalt, I973) and Streptococcus mutans could be divided into four species. Such classifications would be unacceptable to many microbiologists and clinicians. Without DNA hybridization techniques there would be little argument that $S$. mutans should remain a single species. Despite the presence of different antigens and small biochemical differences, $S$. mutans strains show great overall phenotypic similarity. However, we know that significant genetic disparities also exist within $S$. mutans. Should the four genetic groups be considered four separate species? This may be reasonable on genetic grounds. On other grounds it would present difficulties. Tests such as fermentation of raffinose and the production of ammonia from arginine serve to identify genetic groups among the strains in this study but may not be completely predictive for all future isolates. Thus, laboratories lacking specific $S$. mutans antisera and equipment for DNA analysis could not reliably separate four 'mutans-like' species. Furthermore, $S$. mutans strains of all genetic groups have been found in human mouths, and since there is no evidence that one is more cariogenic for humans than another it would be clinically unimportant to consider these organisms as four separate species. Yet, for those who are probing the metabolism, genetics, pathogenic mechanisms and epidemiology of $S$. mutans the existence of four 'genotypes' assumes more importance, for one cannot extrapolate to the whole species the results of experiments on a member of only one genetic group.

In order to give some taxonomic status to the four types of Streptococcus mutans, it is suggested that the genetic groups be considered subspecies. The biochemical features of these subspecies are based only on the strains included in this study. The number of strains is small, and the phenotypic differences among the subspecies are small. Thus the proposed subspecies should be considered genotypes, but not necessarily phenotypes. The binomial Streptococcus mutans will continue to denote a streptococcus which ferments mannitol, usually ferments sorbitol and raffinose, produces glucan from sucrose, and is not an enterococcus.

1. Streptococcus mutans subsp. mutans (Clarke, 1924). Gram-positive cocci in pairs and chains. Mannitol, sorbitol, raffinose and inulin fermented. Glucan produced from sucrose. Grow in air but $\mathrm{CO}_{2}$ required for optimum growth. Ammonia not produced from arginine. DNA base composition 36 to $38 \mathrm{~mol} \%$ guanine plus cytosine. Strains in this subspecies react with Bratthall group $c$ antiserum. Some strains also react with Lancefield group E antiserum.

Clarke's original strains no longer exist, but NCTCI0449 was deposited by W. Sims as a 'representative strain of $S$. mutans' (Edwardsson, 1968) and has been shown to resemble Clarke's original description (Edwardsson, I 968; Guggenheim, I968). Therefore, NCTCI0449 is designated the neotype strain of the species.

2. S. mutans subsp. rattus subsp. nov. (rat'tus). M.L. n. from E. rat. Originally isolated from a rat (genus Rattus). Gram-positive cocci in pairs and chains. Mannitol, sorbitol, raffinose and inulin fermented. Glucan produced from sucrose. Grow in air but $\mathrm{CO}_{2}$ 


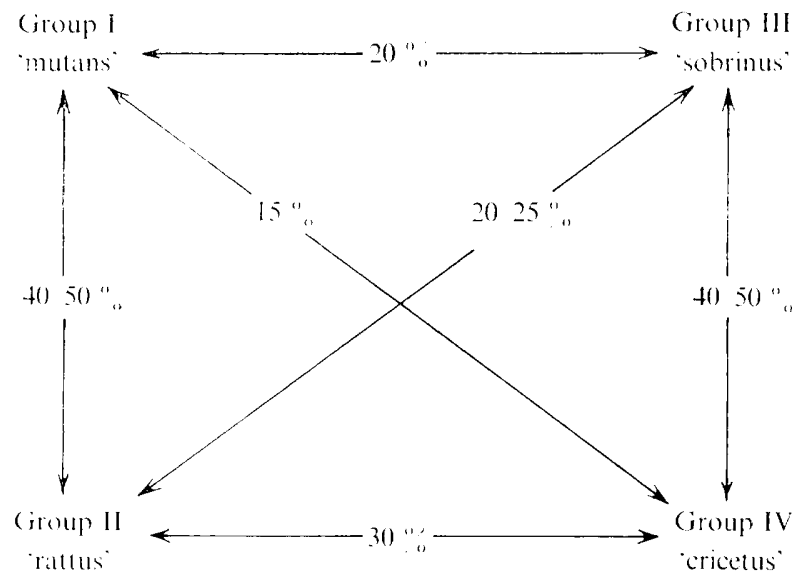

Fig. 3. Approximate intergroup homologies. With one exception ( $(\mathrm{LM} 7=76 \%$ ), strains within a group were at least $85 \%$ homologous, with many approaching $100 \%$. For exact values see Tables 2 and 3, and Coykendall (1971).

Table 4. Summary of the four subspecies of Streptococcus mutans and their characteristics

\begin{tabular}{|c|c|c|c|c|c|}
\hline Subspecies & $\begin{array}{l}\text { Genetic } \\
\text { group* }\end{array}$ & $\begin{array}{c}\text { Serologic } \\
\text { group } \dagger\end{array}$ & $\begin{array}{l}\text { DNA base } \\
\text { content } \\
(\% \mathrm{G}-\mathrm{C})\end{array}$ & $\begin{array}{c}\text { Wall } \\
\text { carbohydrates } \S\end{array}$ & Other distinguishing features \\
\hline $\begin{array}{l}\text { S. mutans subsp. } \\
\text { mutans }\end{array}$ & I & $c$ & $36-38$ & $\begin{array}{l}\text { Glucose } \\
\text { Rhamnose }\end{array}$ & $\begin{array}{l}\text { Slow glycolysis of fructose when } \\
\text { grown on glucose; some strains } \\
\text { Lancefield E }\end{array}$ \\
\hline $\begin{array}{l}\text { S. mutans subsp. } \\
\text { rattus }\end{array}$ & II & $b$ & $4 I-43$ & $\begin{array}{l}\text { Galactose } \\
\text { Rhamnose }\end{array}$ & Produces ammonia from arginine \\
\hline $\begin{array}{l}\text { S. mutans subsp. } \\
\text { sobrinus }\end{array}$ & 111 & $d$ & $44-46$ & $\begin{array}{l}\text { Glucose } \\
\text { Galactose } \\
\text { Rhamnose }\end{array}$ & Does not ferment raffinose \\
\hline $\begin{array}{l}\text { S. mutans subsp. } \\
\text { cricetus }\end{array}$ & IV & 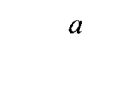 & 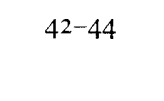 & $\begin{array}{l}\text { Glucose } \\
\text { Galactose } \\
\text { Rhamnose }\end{array}$ & Does not grow in air \\
\hline \multicolumn{6}{|c|}{$\begin{array}{l}* \text { Coykendall (1971). } \\
\text { H Batthall (I972). } \\
\text { Coykendall (I970) an } \\
\$ \text { Hardie \& Bowden, in }\end{array}$} \\
\hline
\end{tabular}

required for optimum growth. Ammonia produced from arginine. DNA base composition 4 I to $43 \mathrm{~mol} \%$ guanine plus cytosine. Strains in this subspecies react with Bratthall group $b$ antiserum. Strain FAI (ATCC19645) is designated the type strain of the subspecies.

3. S. mutans subsp. sobrinus subsp. nov. (so-bri'nus). L. masc. n. sobrinus male cousin on the mother's side. This subspecies is the least related to $S$. mutans subsp. mutans. Grampositive cocci in pairs and chains. Mannitol, inulin, and usually sorbitol fermented. Raffinose not fermented. Glucan produced from sucrose. Ammonia not produced from arginine. Grow in air but $\mathrm{CO}_{2}$ required for optimum growth. DNA base composition 44 to $46 \mathrm{~mol} \%$ guanine plus cytosine. Strains in this subspecies react with Bratthall $d$ antiserum. Strain SLI is designated the type strain of the subspecies.

4. S. mutans subsp. cricetus subsp. nov. (crice-tus). M.L. From Czech Krecek hamster. Originally isolated from a hamster (genus Cricetus, or Mesocricetus). Gram-positive cocci 
in pairs and chains. Mannitol, sorbitol, raffinose and inulin fermented. Glucan produced from sucrose. $\mathrm{CO}_{2}$ or reduced oxygen tension required for growth. Ammonia not produced from arginine. DNA base composition 42 to $44 \mathrm{~mol} \%$ guanine plus cytosine. Strains in this subspecies react with Bratthall group $a$ antiserum. Strain HS6 (ATCCI9642) is designated the type strain of the subspecies.

The characteristics of the four subspecies are summarized in Table 4. Intergroup homologies are summarized in Fig. 3. It should be borne in mind that intergroup hybrids have been shown to contain some nonspecific base pairings (Coykendall, 197I). Thus the true degree of intergroup relatedness is probably lower.

Part of this work was done at the Naval Dental Research Institute. I wish to thank the staff of that Institute, and especially S. Shelton, for their support. I thank G. Dunny and D. Clewell (University of Michigan, Ann Arbor) and Frank Tyeryar (Naval Medical Research Institute, Bethesda) for providing data on the $\mathrm{G}-\mathrm{C}$ contents of some strains. I am indebted to A. Brown for electrophoresis of mannitol-I-phosphate dehydrogenases. I thank D. Bratthall for many helpful discussions.

\section{REFERENCES}

Abercrombif, G. F. \& Scott, W. M. (1928). A case of infective endocarditis due to Streptococcus mutans. Lancet ii, 697-699.

Appleton, J. L. T., Jun. (1933). Bacterial Infection. Philadelphia: Lea \& Febiger.

BRATthall, D. (1970). Demonstration of five serological groups of streptococcal strains resembling Streptococcus mutans. Odontologisk revy 2I, 143--152.

Bratthall, D. (1972). Immuno-fluorescent identification of Streptococcus mutans. Odontologisk revy 23, I 8 I-196.

Brenner, D. J., Fanning, G. R., Miklos, G. V. \& Steigerwalt, A. G. (i973). Polynucleotide sequence relatedness among Shigella species. International Journal of Systematic Bacteriology 23, I-7.

Brown, A. T. \& Patterson, C. E. (1972). Heterogeneity of Streptococcus mutans strains based on their mannitol-I-phosphate dehydrogenases: criterion for rapid classification. Infection and Immunity 6, $422-424$.

Brown, A. T. \& Wittenberger, C. L. (1972). Fructose-I,6-diphosphate-dependent lactate dehydrogenase from a cariogenic streptococcus: purification and regulatory properties. Journal of Bacteriology IIo, $604-615$.

CARLSSON, J. (1967). Presence of various types of non-hemolytic streptococci in dental plaque and in other sites of the oral cavity in man. Odontologisk revy 18, 55-74.

CARLSSON, J. (1968). A numerical taxonomic study of human oral streptococci. Odontologisk revy I9, I 37-I60.

CLARKE, J. K. (1924). On the bacterial factor in the aetiology of dental caries. British Journal of Experimental Pathology 5, I4I-147.

COYKendall, A. L. (1970). Base composition of deoxyribonucleic acid isolated from cariogenic streptoccoci. Archives of Oral Biology 15, 365-368.

Coykendall, A. L. (1971). Genetic heterogeneity in Streptococcus mutans. Journal of Bacteriology ro6, I92-I96.

Coykendall, A. L., Daily, O. P., Kramer, M. J. \& Beath, M. E. (I971). DNA-DNA hybridization studies of Streptococcus mutans. Journal of Dental Research 50, I I I-I 139.

Cullen, G. A. (1967). Classification of Streptococcus uberis with biochemical tests. Research in Veterinary Science 8, 83-88.

Deibel, R. H., Yao, J., Jacobs, N. J. \& Niven, C. F. (I964). Group E streptococci. I. Physiological characterization of strains isolated from swine cervical abscesses. Journal of Infectious Diseases 114, 327-332.

DeNHARDT, D. T. (1966). A membrane-filter technique for the detection of complementary DNA. Biochemical and Biophysical Research Communications 2:3, 641-646.

Drucker, D. B. \& Melville, T. H. (1971). The classification of some oral streptococci of human or rat origin. Archives of Oral Biology 16, 845-853. 
Dunny, G. M., Hausner, T. \& Clewell, D. B. (1972). Buoyant densities of DNA from various strains of Streptococcus mutans. Archives of Oral Biology 17, $100 \mathrm{I}-\mathrm{I} 003$.

Edwardsson, S. (1968). Characteristics of caries-inducing human streptococci resembling Streptococcus mutans. Archives of Oral Biology 13, 637-646.

Englander, H. R. \& Jordan, H. V. (1972). Relation between Streptococcus mutans and smooth surface caries in the deciduous dentition. Journal of Dental Research 5I, 1505.

Fitzgerald, D. B. \& Fitzgerald, R. J. (1965). Induction of dental caries in gerbils. Archives of Oral Biology II, 139-I40.

Fitzgerald, R. J., Jordan, H. V. \& Stanley, H. R. (1960). Experimental caries and gingival pathologic changes in the gnotobiotic rat. Journal of Dental Research 39, 923-935.

Fitzgerald, R. J. \& Keyes, P. H. (1960). Demonstration of the etiologic role of streptococci in experimental caries in the hamster. Journal of the American Dental Association 6I, 9-19.

GibBons, R. J. (1964). Metabolism of intracellular polysaccharide by Streptococcus mitis and its relation to inducible enzyme formation. Journal of Bacteriology 87, 1512-1520.

Gibbons, R. J. (1972). Presence of an invertase-like enzyme and a sucrose permeation system in strains of Streptococcus mutans. Caries Research 6, I22-13 I.

Gibbons, R. J. \& Banghart, S. B. (1967). Synthesis of extracellular dextran by cariogenic bacteria and its presence in human dental plaque. Archives of Oral Biology 12, I1-24.

Gibbons, R. J., Berman, K. S., Knoettner, P. \& Kapsimalis, B. (ig66). Dental caries and alveolar bone loss in gnotobiotic rats infected with capsule forming streptococci of human origin. Archives of Oral Biology II, $549-560$.

Gibbons, R. J. \& Fitzgerald, R. J. (1968). Dextran-induced agglutination of Streptococcus mutans and its potential role in the formation of dental plaques. Journal of Bacteriology 98, 34I-346.

Guggenheim, B. (1968). Streptococci of dental plaques. Caries Research 2, 147-I63.

Guggenheim, B., König, K. G. \& Mühlemann, H. R. (I965). Modifications of the oral flora and their influence on dental caries in the rat. I. The effects of inoculating 4 labelled strains of streptococci. Helvetica odontologica acta $\mathbf{9}, \mathbf{I} 2 \mathbf{I}-\mathbf{I} 29$.

Guggenheim, B. \& Schroeder, H.E. (1967). Biochemical and morphological aspects of extracellular polysaccharides produced by cariogenic streptococci. Helvetica odontologica acta II, I3 I-I 52 .

Hardie, J. M. \& Bowden, G. H. (I97I). Carbohydrate components of the cell walls of Streptococcus mutans and the possible value in serological grouping. Caries Research 6, 80-8I.

Hoerman, K. C., Keene, H. J., Shk lair, I. L. \& Burmeister, J. A. (I972). The association of Streptococcus mutans with early carious lesions in human teeth. Journal of the American Dental Association 85, $1349-1352$.

KrasSE, B. (1966). Human streptococci and experimental caries in hamsters. Archives of Oral Biology II, $429-436$.

Krasse, B., Jordan, H. V., Svensson, I. \& Trell, L. (I968). The occurrence of certain 'caries-inducing' streptococci in human dental plaque material. Archives of Oral Biology r3, 9I I-918.

Kuramitsu, H. K. (I973). Characterization of invertase activity from cariogenic Streptococcus mutans. Journal of Bacteriology 115, 1003-1010.

LANCEFIELD, R. C. (I933). A serological differentiation of human and other groups of hemolytic streptococci. Journal of Experimental Medicine 57, 57I-595.

Maclean, I. H. ( 1927). The bacteriology of dental caries. Proceedings of the Royal Society of Medicine 20, $873-878$.

Marmur, J. \& Doty, P. (1962). Determination of the base composition of deoxyribonucleic acid from its thermal denaturation temperature. Journal of Molecular Biology 5, 109-1 I8.

MCCabe, R. M., Keyes, P. H. \& Howell, A., Jun. (1967). An in vitro method for assessing the plaque forming ability of oral bacteria. Archives of Oral Biology 12, I653-1656.

DE Moor, C. E. \& THAL, E. (1968). Beta haemolytic streptococci of the Lancefield groups E, P and U: Streptococcus infrequens. Antonie van Leeuwenhoek 34, 377-387.

Newbrun, E. ( 1972). Extracellular polysaccharides synthesized by glucosyl-transferases of oral streptococci. Caries Research 6, I32-147.

Niven, C. F., Smiley, K. L. \& Sherman, J. M. (1942). The hydrolysis of arginine by streptococci. Journal of Bacteriology 43, 65I-660.

Schildkraut, C., Marmur, J. \& Doty, P. (1962). Determination of the base composition of deoxyribonucleic acid from its buoyant density in CsCl. Journal of Molecular Biology 4, 430-443. 
Shklair, I. L., Kefne, H. J. \& Simonson, L. G. (1972). Distribution and frequency of Streptococcus mutans in caries-active individuals. Journal of Dental Research $\mathbf{5 1}, 882$.

DE StoppelaAr, J. D. (1971). Streptococcus mutans, Streptococcus sanguis and dental caries. Thesis, University of Utrecht.

de Stoppelaar, J. D., van Houte, J. \& Backer Dirks, O. (1969). Relationship between extracellular polysaccharide-producing streptococci and smooth surface caries in 13-year-old children. Caries Research 3, 190-199.

TANZER, J. M. (1972). Studies on the fate of the glucosyl moiety of sucrose metabolized by Streptococcus mutans. Journal of Dental Research 5I, 4I 5-423.

TANzer, J. M., Brown, A.T. \& MClNerney, M. F. (1973). Identification, preliminary characterization and evidence for regulation of invertase in Streptococcus mutans. Journal of Bacteriology r16, 192-202.

Tanzer, J. M., Brown, A. T. \& Meyers, K. I. (1972). Sucrose dissimilation by Streptococcus mutans independent of glycosyl and fructosyl transferase. Program and Abstracts of Papers, Fiftieth General Session International Association for Dental Research, p. 106.

VAN Houte, J., DE Moor, C. E. \& JANSEN, H. M. (1970). Synthesis of iodophilic polysaccharide by human oral streptococci. Archives of Oral Biology r5, 263-266.

Wood, J. M. (1967). A dextransucrase activity from streptococcus FA-I. Archives of Oral Biology 12, I $659-1660$.

Zinner, D. D. \& JABLon, J. M. (1968). Hunlan streptococcal strains in experimental caries. In Art and Science of Dental Caries Research, pp. 87-109. Edited by R. S. Harris. New York: Academic Press.

Zinner, D. D., Jablon, J. M., Aran, A. D. \& Saslaw, M. S. (1965). Experimental caries induced in animals by streptococci of human origin. Proceedings of the Society for Experimental Biology and Medicine $\mathbf{1} 8$, $766-770$. 